\title{
Article
}

\section{The Influence of Forest Activities in a University Campus Forest on Student's Psychological Effects}

\author{
Jin Gun Kim ${ }^{1}$, Jinyoung Jeon ${ }^{1}\left[\right.$ and Won Sop Shin ${ }^{2, *}$ (D) \\ 1 Graduated Department of Forest Therapy, Chungbuk National University, Cheongju 28644, Korea; \\ jingun0308@naver.com (J.G.K.); forest-bb@naver.com (J.J.) \\ 2 Department of Forest Sciences, Chungbuk National University, Cheongju 28644, Korea \\ * Correspondence: shinwon@chungbuk.ac.kr; Tel.: +82-43-261-2536
}

check for updates

Citation: Kim, J.G.; Jeon, J.; Shin, W.S. The Influence of Forest Activities in a University Campus Forest on Student's Psychological Effects. Int. J. Environ. Res. Public Health 2021, 18 , 2457. https://doi.org/10.3390/ ijerph18052457

Academic Editor: Paul Tchounwou

Received: 21 January 2021

Accepted: 25 February 2021

Published: 2 March 2021

Publisher's Note: MDPI stays neutral with regard to jurisdictional claims in published maps and institutional affiliations.

Copyright: (c) 2021 by the authors. Licensee MDPI, Basel, Switzerland. This article is an open access article distributed under the terms and conditions of the Creative Commons Attribution (CC BY) license (https:/ / creativecommons.org/licenses/by/ $4.0 /)$.

\begin{abstract}
This study aimed to examine the psychological effects of forest activities in a campus forest. A pre-test and post-test control group design was employed to evaluate the psychological effect of forest activities in a campus forest. A total of 38 participants participated in this study (19 in the forest activities group; 19 in the control group). The Profile of Mood State (POMS) questionnaire, the Concise Measure of Subjective Well-Being (COMOSWB), and the modified form of the Stress Response Inventory (SRI-MF) were administered to each participant to assess psychological effects. This study revealed that participants in the forest activities intervention group had significantly positive increases in their mood, stress response, and subjective well-being, comparing with those of control group participants who did not partake in any forest activities. In conclusion, the implementation of forest activities in a campus forest is an efficient strategy to provide psychological well-being benefits to college students.
\end{abstract}

Keywords: forest therapy; campus forest; profile of mood state; subjective well-being

\section{Introduction}

The world has become an urban society, with many populations becoming alienated from the traditional people-nature relationship. According to the World Health Organization [1], more than half of the world's population lived in urban environments in 2014, and this will increase to $65 \%$ by 2030 . Urbanization, defined as the increase in the number of cities and urban population, is a demographic movement and includes social, economic, and psychological changes that constitute the demographic movement. It is a process that leads to the growth of cities due to industrialization and economic development [2]. Urbanization provides us with many opportunities, such as rapid economic growth, but overexposure to stress causes mental health problems [3,4]. Namely, urbanization affects mental health by increasing stressors and factors such as overcrowding and polluted environment, high levels of violence, and reduced social support [5].

In such a situation, mental health is an increasingly urgent public health problem, highlighted by an increase in mental illness such as depression and anxiety [6,7]. This mental health crisis is a particular concern on college campuses. Students encounter stressors, including academic and extracurricular demands, relationships, financial concerns, familial expectations, identity development, and racial and cultural differences. In recent years, there has been an increase in reported symptoms of mental health in college student populations. According to the 2019 National College Health Assessment [8], 87\% of students felt overwhelmed in the past 12 months by all the work they had to do. In addition, $65 \%$ of students reported feeling overwhelming anxiety, and $70 \%$ of students felt very sad and, $45 \%$ of the students suffered from depression. Gallager [9] and Mackean [10] reported that college students had increased mental health problems such as depression, anxiety, suicidal thoughts, and other chronic psychiatric disorders compared to the general population. Research suggests that students have mental problems due to the pressure of academics, 
taking exams, transitioning into college life [11], relationship problems with a peers and romantic partners [12], financial concerns, and familial expectations [13]. Hence, mental health issues among college students can negatively affect academic performance [14,15], relationship dysfunction [16], a high rate of drinking [17,18] and substance abuse [19,20], and increased incidence of suicide [21]. Therefore, it is important to employ effective interventions for coping with a college student's mental health problems.

The use of forests and forest therapy is increasingly recognized as an effective intervention for dealing with physical and psychological problems [22,23]. Many studies demonstrated that using forests helps to reduce stress and enhance physiological relaxation [24-27]. For instance, forest activities, such as walking through a forest or viewing the landscape, can also increase parasympathetic nervous activity [26-28], suppress sympathetic nervous activity $[29,30]$, reduce the cortisol concentration [24,31], pulse rate, and blood pressure [28,31], and improve the immune system [32-34]. Park et al. [31] reported that the forest walking group demonstrated reduced cortisol levels, blood pressure, heart rate, and sympathetic nervous activity and improved parasympathetic nervous activity compared to the city walking group. Studies by Li et al. [32] investigated the impact of forest trips on natural killer (NK) cell activity for two nights and three days on 12 men with weakened immune function. The results demonstrate that forest activities improve weakened immune function. A further study conducted on women also reported that weakened NK cell activity positively affected male and female participants [33]. In addition, increased NK cell activity was maintained for one week for both men and women, and in the case of men, the long-term effect of forest healing was revealed through the results, in that it was maintained until 1 month later [34].

In addition, regarding psychological relaxation aspects, the effects of forest therapy were associated with improved mood state $[35,36]$, self-esteem $[37,38]$, and quality of life [39,40], decreased psychological stress [41,42], depression and anxiety [43-45]. For example, Kaplan and Kaplan [46] argued that individual mental fatigue could be restored through contact with the natural environment, such as the forest. Ulrich et al. [47] demonstrated that natural scenery, such as forests, relieves psychological stress. Shin et al. [48] assessed the impact of forest environment on individual psychological health and wellbeing and the forest experience contribution to emotional and cognitive health promotion. Regarding the more direct impact of natural environments, such as forests, Pretty et al. [49] reported that participants' mood and self-esteem improved significantly after forest exercise. Park et al. [50] showed that walking through a forest reduces negative emotions such as tension, anxiety, depression, anger, fatigue, and improves positive emotions such as vigor. In a similar study, Morita et al. [51] reported that staying and walking in the forest reduces hostility and depression and increases vigor, and further study showed that walking in the forest improves the amount of sleep and reduces the anxiety of participants [52]. To further clarify the psychological effects of forests, Song et al. [36] divided 624 college students into 52 groups to walk through the forest and urban environment. The results show that participants who walked in the forest environment experienced decreased negative emotions such as depression, tension, anger, fatigue, and confusion and increased positive emotions such as vigor, compared with participants who walked in the city environment, and participants with high anxiety experienced a greater effect from the forest in improving depression than those with general or low anxiety.

Many studies demonstrated that exposure to nature, such as forests, improves cognitive tasks that require direct attention. For example, Tennessen and Cimprich [53] showed that the student who can see the natural environment through dormitory windows performed better in tasks requiring concentration than those who did not. Taylor et al. [54] also reported that children who could see urban forests near their apartments performed better in tasks relating to memory, impulse control, selective attention, and concentration than those who did not. Similarly, it has been shown that walking in the natural environment, such as forests, provides advantages in language work memory and cognitive control compared with walking in an urban environment [55-57]. 
However, due to the busy college life of students, interaction with forests far away from cities is limited. Therefore, we need to utilize the campus forest to improve students' quality of life. Campus forests are forests in the university campus space [58]. Campus forests are considered meaningful places for experiencing everyday life, with the potential to support healthy campus planning $[59,60]$. Campus forests are pre-existing, easily accessible, and effective resources for health [60]. Students who spend most of their time on campus walk by and through these spaces daily. Therefore, it could be a good idea to use campus forests to manage university students' mental health. Campus forests have recently been placed on the list of important urban green spaces, drawing more attention to them than in the past $[61,62]$. Campus forests can connect green networks in the inner city and contribute to forming a community with residents. On university campuses, green space is desirable, and represents a precious amenity to help recruit and retain students, promote student loyalty and pride, attract donors, and improve campus quality of life [63].

Some studies suggest the use of campus forests to help college students. Tudorie et al. [64] reported that a campus forest provides a place to relax, meet friends, and pass through. It also has a high potential to provide cultural, provisioning, and regulation landscape services. The content and greenness of the view from indoors on campus can improve indoor settings' perceived restorativeness [65]. Campus forests also can improve the quality of life and mental health benefits for college students. For example, McFarland et al. [66] showed that college students' use of campus forests is associated with their quality of life. Hipp et al. [67] also reported that college students who have higher levels of greenness on-campus show a higher quality of life. In addition, Bang et al. [68] also reported that a campus forest walking program significantly increased health-promoting behaviors and parasympathetic nerve activity and decreased depression. Using 558 voluntary college students, Ibes et al. [60] investigated the psychological impact of green micro-breaks on stress reduction. This study revealed that green micro-break interventions provided a significant psychological impact-most commonly, relief from stress. Therefore, utilizing campus forests may serve as an effective strategy to help students to alleviate mental health problems.

Even though a few studies positively evaluated campus forests for alleviating mental health problems, there is still a lack of research in this area. More research evidence is also needed on the health benefits of the use of campus forests. Therefore, this study aimed to investigate whether students' forest activities influenced their psychological states.

The following research hypotheses were formulated and tested in the study:

(1) Campus forest activities will have a positive effect on mood (on the POMS: The Profile of Mood State scale);

(2) Campus forest activities will have a positive effect on stress response (on the modified form of the Stress Response Inventory: SRI-MF scale);

(3) Campus forest activities will have a positive effect on happiness (on the COMOSWB: Concise Measure of Subjective Well-Being scale).

\section{Materials and Methods}

\subsection{Participants}

Thirty-eight university students (mean age, $22.1 \pm 1.6$ years) were recruited for the field experiment. The distribution of participants was 24 males (mean age, $22.7 \pm 1.4$ years; $63.2 \%$ ) and 14 females (mean age, $21.2 \pm 1.4$ years; $36.8 \%$ ). Recruitment posters were posted throughout the university buildings to recruit volunteers. No incentive was provided to the volunteers. The inclusion criteria required the participants to be current students at the specified university. Participants who met the following inclusion and exclusion criteria were considered for study: (1) no diagnosis of a reaction to severe stress and/or depression; (2) did not suffer from drug or alcohol abuse. The participants were randomly distributed into two groups (i.e., 19 in the campus forest activities group and 19 in the control group). The details of participants' characteristics are shown in Table 1. 
Table 1. Instructions given to the two groups of participants during the study period.

\begin{tabular}{|c|c|}
\hline Group & Direct Request \\
\hline Activity group & $\begin{array}{l}\text { Read and follow the instructions on the guide signs for each } \\
\text { activity installed on the course. } \\
\text { Do individual activities, not group activities, when performing } \\
\text { forest activities } \\
\text { Keep normal life during the experiment } \\
\text { Avoid alcohol and tobacco during the experiment } \\
\text { Do forest activities regularly (At least once a week) }\end{array}$ \\
\hline Control group & $\begin{array}{l}\text { Keep normal life during the experiment } \\
\text { Avoid alcohol and tobacco during the experiment }\end{array}$ \\
\hline
\end{tabular}

The experiment was conducted during the 2nd semester of 2019 (September-November). A total of eight sessions of forest activities were performed. Before starting the experiments, we explained the study's purpose and procedures and obtained their written informed consent. The Institutional Review Board of Chungbuk National University (IRB number: CBNU-201910-SB-945-01) approved this study.

\subsection{Experimental Site}

The field experiment site was conducted in the Chungbuk National University campus forest in Korea. The size of campus forest is about $315,000 \mathrm{~m}^{2}$, covered mainly by Metasequoia glyptostroboides (DBH 44cm; tree height 22-27 m; 0.2 ha), Chamaecyparis pisifera (DBH $34 \mathrm{~cm}$; tree height 12-18 m; $0.25 \mathrm{ha}$ ), and mixed forest species (pitch pine, oak, chestnut, oriental cherry; $2.7 \mathrm{ha}$ ), and the stand age ranged between 40 and 90 years old. The study area was a suitable place for conducting forest activities in terms of accessibility, distribution of a variety of vegetation, and gentle slope. During the eight sessions in the experiment, the weather was pleasant and not raining, with a mean temperature of $16.2 \pm 1.3^{\circ} \mathrm{C}$.

\subsection{Procedure}

The study employed a pretest-posttest control group experimental design [69]. Participants' psychological states were measured before and after the intervention. The participants were instructed to perform forest activities for eight sessions (one hour-long session per week). We designed the forest activities to be performed voluntarily (see Figure 1). To perform forest activities, an instruction booklet was administered to each participant. The instruction leaflet was developed based on consultation from experts in the forest therapy field, including researchers and practitioners. Five forest activities were selected in this study to apply as the campus forest activities intervention: stretching, respiration, walking, meditation, and exercise.

The forest activities interventions were provided from September to November of 2019. The interventions were performed once a week during the daytime, depending on participants' preferred schedule. During each of the eight sessions in the intervention, participants were asked to walk along the designated route in the campus forest, visit specific locations where explanatory panels on forest activities were installed, and return to the starting point at an appointed time. (see Figure 2). In the first session of the intervention, the leaflet was distributed to each participant. We asked the participants to perform the forest activities intervention at least once a week according to the leaflet's instructions. Details regarding the instructions used for each activity are included in Appendix A. The participants in the control group did not receive leaflets, lectures, or any forest activities, and were asked to follow out their routine activities during the experimental period. The requests provided to both groups of participants during the intervention are shown in Table 1. 


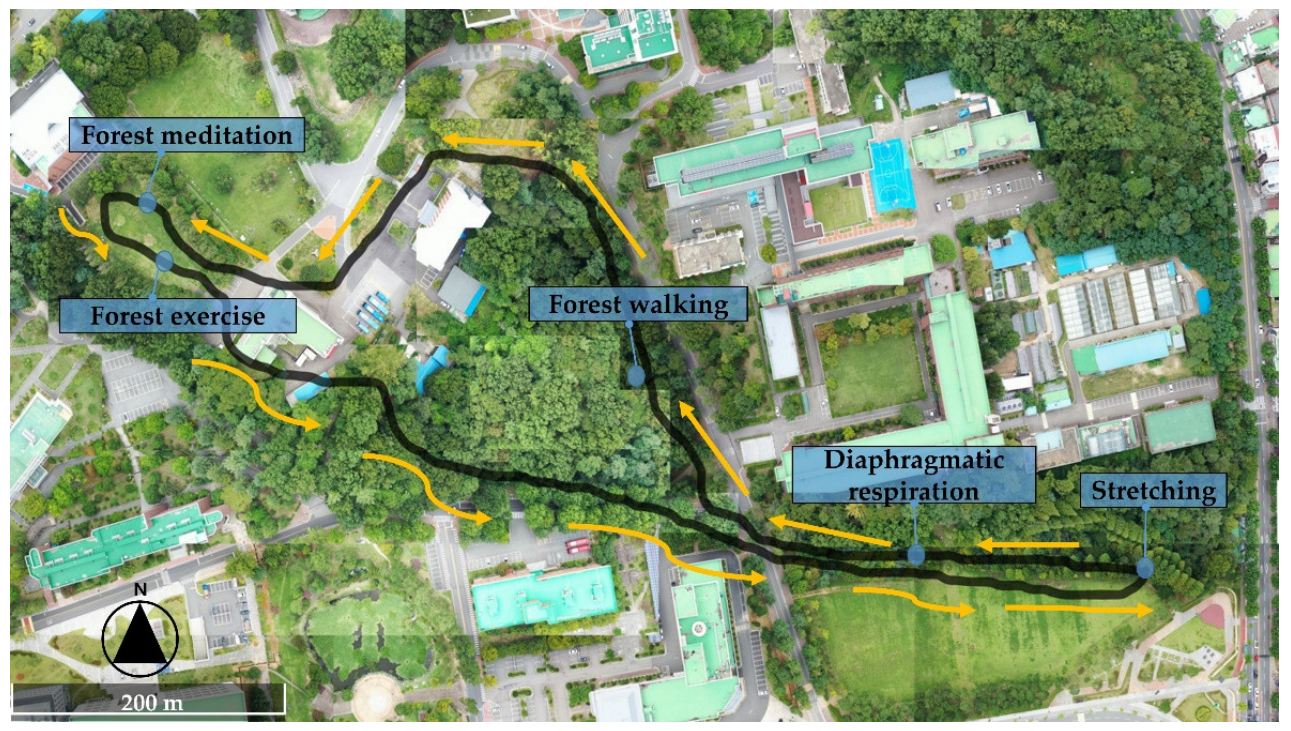

Figure 1. Maps of the campus forest activities trail in this study.

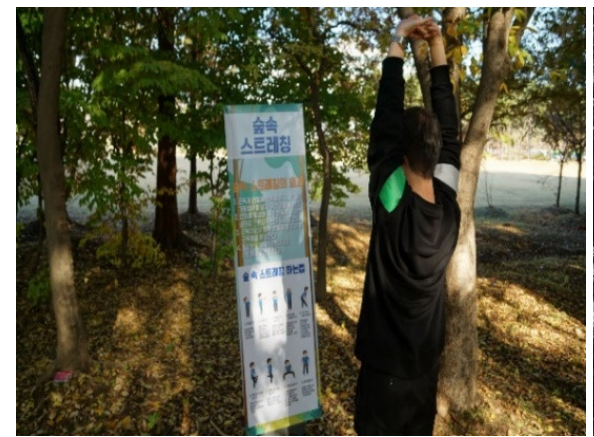

(A) stretching

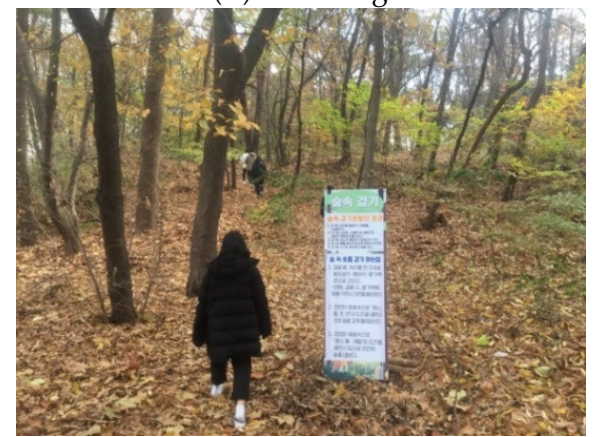

(C) walking

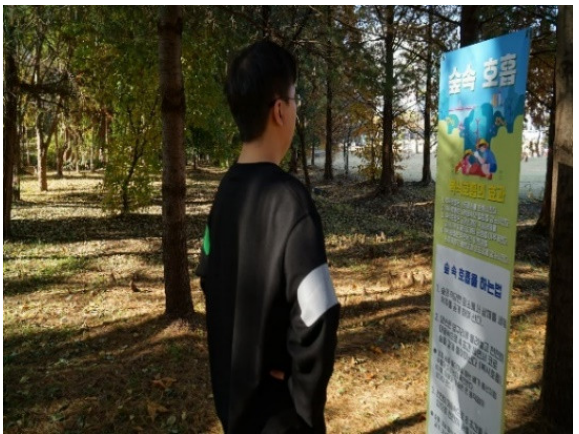

(B) respiration

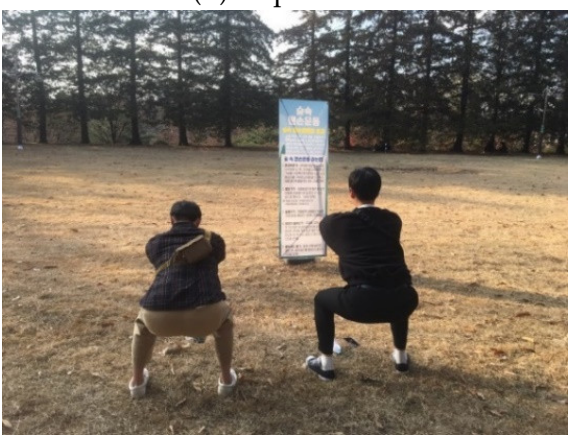

(D) exercise

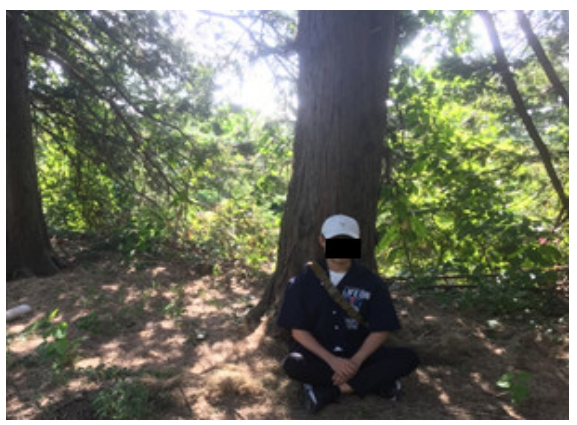

(E) meditation

Figure 2. Campus forest activities intervention. 


\subsection{Psychological Measurement}

The psychological evaluations used the Profile of Mood States (POMS), the modified form of the Stress Response Inventory (SRI-MF), and the Concise Measure of Subjective Well-being (COMOSWB) questionnaires. The POMS is a well-established measure of emotional state and is a reliable and valid instrument for assessing psychological distress [70,71], and has been used previously to estimate the influence of a forest experience on mood states [71-74]. It simultaneously evaluates six mood states: "tension-anxiety $(\mathrm{T}-\mathrm{A})$ ", " depression-dejection (D)", "anger-hostility $(\mathrm{A}-\mathrm{H})$ ", "fatigue (F)", "confusion $(\mathrm{C})$ ", and "vigor $(\mathrm{V})$ " [70,71]. A five-point Likert scale $(0=$ strongly agree to $4=$ strongly disagree) was used for each item to evaluate each participant's mood state. In this study, we employed the short form of the Korean version of the POMS (30 items) [75]. The Korean version of POMS was revealed to have relatively high reliability (Cronbach's $\alpha=0.85$ ).

The SRI-MF was used to assess the participants' stress response levels. The SRI-MF is a self-reported tool that measures the participant's stress response levels, including somatization, anger, and depression [76,77]. The SRI-MF is a key measurement tool concerning stress, particularly the mental health and physical symptoms related to stress [78]. It has been used previously to estimate the effect of a forest therapy program on stress [79]. The SRI-MF has 22 items, and each item has a 5-point Likert scale (1 = strongly disagree; $5=$ strongly agree). The SRI-MF was revealed to have relatively high reliability (Cronbach's $\alpha=0.93$ ) [77].

The COMOSWB was used to assess each participant's subjective well-being states. The COMOSWB measures three sub-scales: life satisfaction, positive emotion, and negative emotion [80]. It has been used previously to estimate the effect of a forest therapy program on happiness [81]. The COMOSWB has a total of nine items with a 7-point Likert scale ( $1=$ strongly disagree; $7=$ strongly agree). The COMOSWB was revealed to have relatively high reliability (Cronbach's $\alpha=0.86$ ) [80].

\subsection{Data Analysis}

The statistical analyses were performed using SPSS 18.0 Windows (SPSS, Chicago, IL, USA). Descriptive statistics comprised means, standard deviation, frequency, and percentage to present socio-demographic information and outcome variables. Paired t-tests were used to compare participants' psychological states between pre-and post-tests for each group (forest activities intervention and control groups). All statistical tests used a $p$-value of $<0.05$ as the significance level.

\section{Results}

3.1. Psychological Measurements

3.1.1. Profile of Mood States (POMS)

The results of paired t-tests between pre-and post-tests POMS scores for each group are presented in the Table 2. As shown in Table 2, there was a significant decrease in Total Mood Disturbance scores for the campus forest activities group after eight sessions of the forest activities intervention $(t=3.976, p<0.01)$. The results of paired $t$-tests indicate that there were significant positive changes in five subscales of the POMS, except for one subscale, entitled "anger-hostility" ( $t=1.882, p>0.05)$ : "tension-anxiety" $(t=2.419$, $p<0.05)$, "depression-dejection" $(\mathrm{t}=2.468, p<0.05)$, "fatigue-inertia" $(\mathrm{t}=5.050, p<0.001)$, "confusion-bewilderment" $(\mathrm{t}=5.175, p<0.001)$, and "vigor" $(\mathrm{t}=-2.733, p<0.05)$.

However, there were no significant changes in the control group participants' changes in Total Mood Disturbance and all six subscales of the POMS: "tension-anxiety", "angerhostility", "depression-dejection", "fatigue-inertia", "confusion-bewilderment", and "vigor". 
Table 2. The results of paired t-test analyses of subjective Profile of Mood State (POMS) scores.

\begin{tabular}{|c|c|c|c|c|c|c|c|c|}
\hline & \multicolumn{4}{|c|}{ CFA } & \multicolumn{4}{|c|}{ Cont. } \\
\hline & Before & After & $t$ & $p$ & Before & After & $t$ & $p$ \\
\hline TMD & $25.16 \pm 4.32$ & $10.68 \pm 4.35$ & 3.976 & 0.001 ** & $20.79 \pm 3.12$ & $21.84 \pm 3.85$ & -0.355 & 0.726 \\
\hline $\mathrm{T}-\mathrm{A}$ & $7.11 \pm 0.96$ & $4.68 \pm 1.12$ & 2.419 & $0.026^{*}$ & $5.95 \pm 0.84$ & $6.42 \pm 0.87$ & -0.590 & 0.563 \\
\hline $\mathrm{A}-\mathrm{H}$ & $4.68 \pm 0.93$ & $3.11 \pm 0.62$ & 1.882 & 0.076 & $5.79 \pm 0.90$ & $5.37 \pm 0.92$ & 0.671 & 0.511 \\
\hline $\mathrm{D}$ & $5.42 \pm 1.04$ & $3.16 \pm 0.64$ & 2.468 & $0.024 *$ & $4.26 \pm 0.68$ & $4.58 \pm 0.74$ & -0.480 & 0.637 \\
\hline $\mathrm{F}$ & $8.95 \pm 0.86$ & $5.42 \pm 0.88$ & 5.050 & $0.000^{* * *}$ & $8.16 \pm 0.53$ & $8.32 \pm 0.77$ & -0.221 & 0.828 \\
\hline $\mathrm{C}$ & $8.37 \pm 0.67$ & $5.74 \pm 0.70$ & 5.175 & $0.000^{* * *}$ & $7.00 \pm 0.54$ & $7.11 \pm 0.60$ & -0.244 & 0.810 \\
\hline V & $9.37 \pm 0.72$ & $11.42 \pm 0.85$ & -2.733 & 0.014 * & $10.37 \pm 0.60$ & $9.95 \pm 0.76$ & 0.522 & 0.608 \\
\hline
\end{tabular}

Notes: T-A, tension-anxiety; A-H, anger-hostility; anger-hostility; D, depression; F, fatigue; C, confusion; V, vigor; TMD, Total Mood Disturbance. Campus forest activities group (CFA) and control group (Cont.). ${ }^{* * *} p<0.001,{ }^{* *} p<0.01,{ }^{*} p<0.05$.

\subsubsection{Modified Form of the Stress Response Inventory (SRI-MF)}

The results of paired t-tests between pre-and post-tests SRI-MF scores for each group are presented in the Table 3. As shown in Table 3, there was a significant decrease in total stress response scores for the campus forest activities group after eight sessions of the campus forest activities intervention $(t=3.745, p<0.01)$. The results of paired $t$-tests indicate that there were significant positive changes in three subscales of the SRI-MF: "somatization" ( $\mathrm{t}=3.481, p<0.01)$, "anger" $(\mathrm{t}=2.645, p<0.05)$, and "depression" $(\mathrm{t}=2.955$, $p<0.01)$.

Table 3. The results of paired $t$-test analysis of modified form of the Stress Response Inventory (SRI-MF) scores.

\begin{tabular}{ccccccccc}
\hline & \multicolumn{4}{c}{ CFA } & \multicolumn{3}{c}{ Cont. } \\
\cline { 2 - 9 } & Before & After & $\mathbf{t}$ & $\boldsymbol{p}$ & Before & After & $\mathbf{t}$ & $\boldsymbol{p}$ \\
\hline Total & $54.16 \pm 3.35$ & $43.53 \pm 3.34$ & 3.745 & $0.001^{* *}$ & $49.42 \pm 2.90$ & $52.05 \pm 3.90$ & -0.795 & 0.437 \\
Somatization & $22.05 \pm 1.46$ & $17.11 \pm 1.44$ & 3.481 & $0.003^{* *}$ & $21.47 \pm 1.37$ & $23.74 \pm 2.07$ & -1.320 & 0.203 \\
Anger & $13.84 \pm 1.01$ & $11.53 \pm 1.04$ & 2.645 & $0.016^{*}$ & $10.89 \pm 0.78$ & $11.58 \pm 0.88$ & -0.646 & 0.527 \\
Depression & $18.26 \pm 1.27$ & $14.89 \pm 1.17$ & 2.955 & $0.008^{* *}$ & $17.05 \pm 1.19$ & $16.74 \pm 1.33$ & 0.317 & 0.755 \\
\hline
\end{tabular}

Notes: Total, Total happiness. Campus Forest activities group (CFA) and Control group (Cont.). ${ }^{* *} p<0.01,{ }^{*} p<0.05$.

However, there were no significant changes in the control group participants' total stress responses and other sub-scales of the SRI-MF: "somatization", "anger", and "depression".

\subsubsection{Concise Measure of Subjective Well-Being (COMOSWB)}

The results of paired t-tests between pre-and post-tests COMOSWB scores for each group are presented in the Table 4. As shown in Table 4, there was a significant increase in total happiness scores for the campus forest activities group after eight sessions of the campus forest activities intervention $(\mathrm{t}=-3.202, p<0.01)$. The results of paired $\mathrm{t}$-tests indicate that there were significant positive changes in two subscales of the COMOSWB: "life satisfaction" ( $\mathrm{t}=-2.996, p<0.01)$, "negative emotion" $(\mathrm{t}=2.750, p<0.05)$. However, there were no significant changes in the subscale titled "positive emotion."

Table 4. The results of paired $t$-test analyses of Concise Measure of Subjective Wellbeing (COMOSWB) scores.

\begin{tabular}{|c|c|c|c|c|c|c|c|c|}
\hline & \multicolumn{4}{|c|}{ CFA } & \multicolumn{4}{|c|}{ Cont. } \\
\hline & Before & After & $t$ & $p$ & Before & After & $t$ & $p$ \\
\hline $\begin{array}{c}\text { Total } \\
\text { happiness }\end{array}$ & $19.05 \pm 1.61$ & $23.21 \pm 1.87$ & -3.202 & $0.005^{* *}$ & $21.42 \pm 1.65$ & $24.00 \pm 1.23$ & -1.784 & 0.091 \\
\hline $\begin{array}{l}\text { Life } \\
\text { satisfaction }\end{array}$ & $14.74 \pm 0.68$ & $16.26 \pm 0.64$ & -2.996 & $0.008^{* *}$ & $16.05 \pm 0.60$ & $16.79 \pm 0.48$ & -1.099 & 0.286 \\
\hline $\begin{array}{l}\text { Positive } \\
\text { emotion }\end{array}$ & $15.16 \pm 0.75$ & $15.63 \pm 0.72$ & -1.027 & 0.318 & $14.84 \pm 0.80$ & $15.95 \pm 0.49$ & -1.293 & 0.212 \\
\hline $\begin{array}{l}\text { Negative } \\
\text { emotion }\end{array}$ & $10.84 \pm 0.82$ & $8.68 \pm 0.93$ & 2.750 & $0.013 *$ & $9.47 \pm 0.78$ & $8.74 \pm 0.81$ & 0.915 & 0.372 \\
\hline
\end{tabular}


On the other hand, there were no significant changes in the control group participants' total happiness and other sub-scales of the COMOSWB: "life satisfaction", "positive emotion", and "negative emotion".

\section{Discussion}

This study evaluated the psychological effectiveness of forest activities in a campus forest. This study revealed that campus forest activities intervention participants had significantly positive mood states, stress responses, and happiness after the intervention. The results of this study indicate that the campus forest provides effectiveness in improving college students' psychological health.

To date, many empirical research results have shown that forest therapy programs carried out in forests far away from the city provide a wide range of psychological health benefits to the program participants $[82,83]$. However, few studies on the psychological effects of campus forest activities have been reported. Therefore, this study suggests that campus forests can help to promote psychological well-being among university students.

This study showed that the negative mood states of "tension-anxiety", "depressiondejection", "fatigue", and "confusion" were lower, and the positive mood states of vigor were significantly higher after campus forest activities intervention. These results, which demonstrate the psychological benefits of campus forest activities, are consistent with previous findings demonstrating improvements in mood states after walking through urban green space [84-86] and forest areas [87,88].

This result also found that the total stress responses and other subscales of the SRIMF such as "somatization", "anger", and "depression" were significantly lower after the campus forest activities. This study confirms that campus forest activities had a significant effect on stress reduction. This is consistent with the results of previous studies showing a reduction in psychological stress after viewing a forest and forest walking [88-90]. For example, Morita et al. [89] reported that forest walking could improve self-rated health status and reduce psychological stress. Marselle et al. [90] showed that nature-based walking reduced perceived stress, depression, and negative emotion and improved positive emotions and mental health. Im et al. [78] reported that forest walking significantly decreased stress response scores compared to city walking. In addition, Khianman et al. [91] demonstrated the stress-reduction effect of forest therapy on various subjects. These findings show that the benefits of forest therapy activities in stress relief are consistently evaluated as significant results.

This study also shows participants' increased happiness levels in the campus forest activities intervention group. The results of this study are consistent with previous studies' improvement of happiness after partaking in forest activities, such as playing in the forest and the forest therapy program. Park et al. [81] reported that employees' subjective happiness increased after participating in four sessions of a forest therapy program. Happiness increased in children who played in forests comparing with those who played in classrooms $[92,93]$. Similar studies have shown that green spaces, including forests, promote a sense of happiness [94]. For example, Luck et al. [95] reported that vegetation cover had the strongest positive relation with personal well-being. According to Lohr and Pearson-Mims [96], people felt more positive emotions and happiness when viewing trees than inanimate objects. Van Herzele and De Vries [97] and MacKerron and Mourato [94] reported that people living adjacent to green space were happier than people living in urban environments. People more related to nature tend to seek more experiences with nature, and benefit from the well-being outcomes from those experiences, such as feelings of positive mood and happiness [98,99]. Promoting participants' happiness offers significant benefits. Happiness can create pleasant moods, positive emotions, positive attitudes toward oneself and others [100], and is known to be significantly linked to reduced heart disease rate $[101,102]$ and mortality $[103,104]$, health and longevity $[105,106]$, and improved sleep [107]. 
The results of this study reveal a positive relationship between students' forest activities and their psychological effects. However, it is not clear whether the psychological effects resulted from the activities the participants performed, the forest activities, or exposure to nature and the forest. Further studies are needed to clarify this relationship. The influence of each forest activity performed by the participants on the psychological effects should also be investigated in further research. In particular, forest walking is one of the most representative activities of forest therapy.

Numerous studies have shown that walking in a forest improves mood state $[87,88]$ and alleviates perceived stress $[89,90]$. Walking in the forest has also been demonstrated to be more effective in improving mental health than walking in the city environment [108]. Diaphragmatic breathing $[109,110]$ and meditation [111-113] in the forest have also reported positive psychological effects in some previous studies. Meditation with deep breathing in the forest increases the connection with nature and improves mental, physical, and emotional well-being [114]. The health promotion effects of outdoor activities were significantly enhanced when meditation was incorporated into nature activities $[115,116]$. Holt et al. [117] showed that students who engaged in the use of campus forests in passive ways, such as sitting, studying, or eating were not associated with health and wellbeing benefits, while students who actively engaged in the use of green space, such as being physically active outdoors, were strongly associated with a higher quality of life, better overall mood, and lower perceived stress. As mentioned above, previous research suggests that time spent in nature in energetic activity can promote restoration and reduce stress and improve happiness [87-93]. Therefore, forest activities' psychological effects through campus forests can be an efficient strategy to improve mental health.

Recent research showed that college students are constantly exposed to stressors and that the college period is an important time, during which young people adopt lasting healthy lifestyle habits, and is associated with increased chronic disease risk $[118,119]$. In particular, mental health problems are important. Across all countries combined, 21.2\% of college students have major depression disorders and $18.6 \%$ have generalized anxiety disorder [120], and they have a higher rate of being diagnosed or treated by a professional for anxiety, depression, panic attacks, and attention deficit hyperactivity disorder (ADHD) [8]. Universities have been increasing their efforts to address this problem in various programs. The programs for students have included initiatives such as mindfulness programs, yoga classes, and pet therapy [121-123]. Although a variety of programs has been used to address students' mental health, the ability of campus forests to help the student is often overlooked. Students, faculty members, and others use campus forests for a walk every day. However, the potential psychological benefits of campus forests are not widely acknowledged [60]. Therefore, this study can demonstrate the psychological health potential and suggest campus forests for health promotion resources to university students and other campus members.

Forest activity in campus forest is an effective and convenient way to escape busy college life and focus only on oneself. Undertaking activities in natural environments reduces stress and anxiety and thus promotes health [124]. Our study suggests promoting opportunities for students to use campus forests and inform ways or activities for students to utilize campus forests to promote mental health. In addition, staff or faculty of the university can use campus forests in leisure activities whenever they can, such as lunchtime or rest time during work, which will help to relieve work stress. In this regard, the university should continue to maintain well-managed campus forests and expand convenient access to paths through natural areas, promoting campus forest or green space use. The university should also support education to increase students' awareness around existing campus forests and the potential mental health benefits from regular use [117].

However, we acknowledge the several limitations of this study. Firstly, this study employed five forest activities (stretching, respiration, walking, meditation, and exercise). It is not clear which activity contributed the most to the results and how the differential effect of each of the activities affected the participants. Further studies are needed to clarify 
and compare the various types of forest activities. Secondly, the sample size of this study was small, and the participants for this study were limited to healthy university students in their 20s. To generalize the findings, further studies are needed create a large sample using different groups of the population with different socio-demographic characteristics. Thirdly, this study was conducted in a campus forest to validate the psychological effect of campus forest activities. The potentials of different forests are not all the same and vary based on forest features. The effects according to the various characteristics of the forests (i.e., tree species composition, forest stand, structure, canopy cover, forest element-related) must be examined in the future. Fourth, participants' prior expectations and experiences with forests may influence the results. Further study is needed considering the extent of exposure to nature in childhood and patterns of visits to forests. Firth, in this study, the control group conducted their usual activities. Some of the control group may use forests for their leisure, and those experiences may influence the results of this study. Therefore, further studies are needed with participants who spend time in forests without giving them any instructions. Sixth, for an overall discussion, verifying the effects of campus forests using other psychological methods is necessary to demonstrate the new possibility to promote students' health. In a further study, it is necessary to investigate in depth what are the important variables that contribute to the psychological effects of campus forests. These limitations should be considered in future research. Despite these limitations, this study provides a notable strength of the forest activities in a campus forest, which is that they are easily accessible to students to use whenever they can.

\section{Conclusions}

This study showed that the campus forest activities intervention provided significant psychological effects on college students. More specifically, there were significant positive changes in participants' emotional states, stress responses, and happiness. The study results indicate the effectiveness of campus forest activities, suggesting the complementary use of different types of forest areas in such a modern urbanized society. These findings can provide guidance to decision-makers on the importance of the campus forest management, and policymakers can utilize these results in order to enhance student's mental health.

Author Contributions: J.G.K. performed data acquisition, statistical analysis, interpretation of the results, and manuscript preparation. J.J. was involved with acquisition of data. W.S.S. had an important a role in the overall performance of this research, particularly experimental design and research idea. All authors have read and agreed to the published version of the manuscript.

Funding: This research received no external funding.

Institutional Review Board Statement: This study was approved by the Institutional Review Board of Chungbuk National University (IRB number: CBNU-201910-SB-945-01).

Informed Consent Statement: Informed consent was obtained from all subjects involved in the study.

Data Availability Statement: The data presented in this study are available on request from the corresponding author. The data are not publicly available due to privacy.

Acknowledgments: We thank the forest healing lab members of Chungbuk National University for their help. We also gratefully thank forest therapists for their valuable guidance.

Conflicts of Interest: The authors declare no conflict of interest.

\section{Appendix A. Campus Forest Activities Signs Text}

(1) Forest stretching signs

(1) Neck rotation: Stand upright with both hands on your waist and turn your neck in one direction for eight beats. Turn it in the opposite direction.

(2) Shoulder rotation: Stand upright with your fingertips on your shoulders and turn your shoulders in a circle. Turn it in the opposite direction. 
(3) Waist rotation: Stand upright with both hands on your waist and turn your waist in one direction. Turn it in the opposite direction.

(4) Knees rotation: Bend your upper body, place your hands on your knees, and turn your knees in one direction. Turn it in the opposite direction.

(5) Wrist and ankle rotation: Lightly rotate both wrists for eight beats while rotating one ankle together.

(2) Forest respiration signs

(1) Stand your upper body in a suitable place in the forest with your spine straightened.

(2) Put your hands on the sides and slowly count ' 1 , 2, 3, 4' (4 s) in your mind and inhale deeply through your nose.

(3) Slowly exhale into your mouth, counting eight seconds in your mind.

(4) Repeat 20 times.

(3) Walking in the Forest signs

(1) When you walk, walk in the order of heel-sole-toe position with your back straight.

(2) Slowly inhale deeply through your nose, counting ' 1 , 2, 3, 4' (4 s) in your mind.

(3) Slowly exhale into your mouth, counting eight seconds.

(4) Forest exercise signs

(1) Push-ups: Stand facing a suitable tree nearby, put your palms on the tree. Bend your elbows and lower your chest to the tree and push through the palms of your hands to straighten your arms (Repeat 10 to 20 times).

(2) Arm pull: Stretch your arms forward, pull your arms backward as hard as possible, and then stretch them forward again (Repeat 30 times).

(3) Squat: First, stand your feet shoulder-width apart. Second, squat down by pushing your knees to the side while moving your hips back. Third, break parallel by Squatting down until your hips are lower than your knees. Finally, press into your heels and straighten your legs to return to an upright standing position (Repeat 20 times).

(4) Core exercise: Keep your knees straight and raise your legs as high as possible (Repeat 10 times on both sides).

(5) Heel raise exercise: Keeping your knees straight, raise your heels up off the floor as far as you can go, and then slowly return (Repeat 30 times).

(5) Forest meditation signs

(1) Sit in a comfortable position with your spine straightened by standing your upper body in a suitable place in the forest.

(2) Slowly inhale deeply through your nose, counting ' 1 , 2, 3, 4' (4 s) in your mind.

(3) Slowly exhale into your mouth, counting eight seconds in your mind.

(4) Now, I feel my thoughts and emotions calm as I find the breathing rhythm and focus on breathing.

(5) If you have miscellaneous thoughts, focus on your breathing.

(6) At this moment, focus fully on the present state.

(7) Close your eyes.

(8) Do it for $5 \mathrm{~min}$.

\section{References}

1. World Health Organization. Urban Population Growth. Available online: http:/ /www.who.int (accessed on 14 August 2019).

2. Turan, M.; Besirli, A. Impacts of urbanization process on mental health. Anadolu Psikiyatri Derg 2008, 9, $238-243$.

3. Lederbogen, F.; Kirsch, P.; Haddad, L.; Streit, F.; Tost, H.; Schuch, P.; Wüst, S.; Pruessner, J.C.; Rietschel, M.; Deuschle, M.; et al. City living and urban upbringing affect neural social stress processing in humans. Nature 2011, 474, 498-501. [CrossRef]

4. McKenzie, K.; Murray, A.; Booth, T. Do urban environments increase the risk of anxiety, depression and psychosis? An epidemiological study. J. Affect. Disord. 2013, 150, 1019-1024. [CrossRef] [PubMed]

5. Srivastava, K. Urbanization and mental health. Ind. Psychiatry J. 2009, 18, 75. [CrossRef]

6. Tiller, J.W. Depression and anxiety. Med. J. Aust. 2013, 199, S28-S31. [CrossRef] [PubMed] 
7. Lun, K.W.; Chan, C.K.; Ip, P.K.; Ma, S.Y.; Tsai, W.W.; Wong, C.S.; Wong, C.H.; Wong, T.W.; Yan, D. Depression and anxiety among university students in Hong Kong. Hong Kong Med. J. 2018, 24, 466-472. [CrossRef] [PubMed]

8. American College Health Association. National College Health Assessment II: Undergraduate Executive Summary Spring 2019; American College Health Association: Hanover, MD, USA, 2019.

9. Gallagher, R.P. National Survey of Counseling Center Directors; The International Association of Counseling Services: Pittsburgh, PA, USA, 2008.

10. MacKean, G. Mental Health and Well-Being in Postsecondary Education Settings: A Literature and Environmental Scan to Support Planning and Action in CANADA. Canadian Association of College and University Student Services. Available online: http:/ / www.cacuss.ca (accessed on 20 August 2020).

11. Robotham, D. Stress among higher education students: Towards a research agenda. High. Educ. 2008, 56, 735-746. [CrossRef]

12. Hurst, C.S.; Baranik, L.E.; Daniel, F. College student stressors: A review of the qualitative research. Stress Health 2013, $29,275-285$. [CrossRef] [PubMed]

13. Kadison, R.; DiGeronimo, T. College of the Overwhelmed: The Campus Mental Health Crisis and What to Do About It; Jossey-Bass: San Francisco, CA, USA, 2004.

14. Hartley, M. Increasing Resilience: Strategies for Reducing Dropout Rates for College Students with Psychiatric Disabilities. Am. J. Psychiatr. Rehabil. 2010, 13, 295-315. [CrossRef]

15. Bruffaerts, R.; Mortier, P.; Kiekens, G.; Auerbach, R.P.; Cuijpers, P.; Demyttenaere, K.; Green, J.G.; Nock, M.K.; Kessler, R.C. Mental health problems in college freshmen: Prevalence and academic functioning. J. Affect. Disord. 2018, 225, 97-103. [CrossRef] [PubMed]

16. Kerr, D.; Capaldi, D. Young men's intimate partner violence and relationship functioning: Long-term outcomes associated with suicide attempt and aggression in adolescence. Psychol. Med. 2011, 41, 759-769. [CrossRef] [PubMed]

17. Geisner, I.; Mallett, K.; Kilmer, J.R. An examination of depressive symptoms and drinking patterns in first year college students. Issues Ment. Health Nurs. 2012, 33, 280-287. [CrossRef]

18. Pedrelli, P.; Borsari, B.; Lipson, S.K.; Heinze, J.E.; Eisenberg, D. Gender differences in the relationships among major depressive disorder, heavy alcohol use, and mental health treatment engagement among college students. J. Stud. Alcohol Drugs 2016, 77, 620-628. [CrossRef]

19. Halperin, A.C.; Smith, S.S.; Heiligenstein, E.; Brown, D.; Fleming, M.F. Cigarette smoking and associated health risks among students at five universities. Nicotine Tob. Res. 2010, 12, 96-104. [CrossRef]

20. Keith, D.; Hart, C.; McNeil, M.; Silver, R.; Goodwin, R. Frequent marijuana use, binge drinking and mental health problems among undergraduates. Am. J. Addict. 2015, 24, 499-506. [CrossRef]

21. Keyes, C.L.; Eisenberg, D.; Perry, G.S.; Dube, S.R.; Kroenke, K.; Dhingra, S.S. The relationship of level of positive mental health with current mental disorders in predicting suicidal behavior and academic impairment in college students. J. Am. Coll. Health 2012, 60, 126-133. [CrossRef]

22. Tsunetsugu, Y.; Park, B.; Miyazaki, Y. Trends in research related to "Shinrin-yoku" (taking in the forest atmosphere or forest bathing) in Japan. Environ. Health Prev. Med. 2010, 15, 27-37. [CrossRef]

23. Song, C.; Ikei, H.; Kobayashi, M.; Miura, T.; Li, Q.; Kagawa, T.; Kumeda, S.; Imai, M.; Miyazaki, Y. Effects of viewing forest landscape on middle-aged hypertensive men. Urban For. Urban Green. 2017, 21, 247-252. [CrossRef]

24. Park, B.; Tsunetsugu, Y.; Kasetani, T.; Kagawa, T.; Miyazaki, Y. The physiological effects of Shinrin-yoku (taking in the forest atmosphere or forest bathing): Evidence from field experiments in 24 forests across Japan. Environ. Health Prev. Med. 2010, 15, 18-26. [CrossRef] [PubMed]

25. Lee, J.; Park, B.; Tsunetsugu, Y.; Ohira, T.; Kagawa, T.; Miyazaki, Y. Effect of forest bathing on physiological and psychological responses in young japanese male subjects. Public Health 2011, 125, 93-100. [CrossRef]

26. Tsunetsugu, Y.; Lee, J.; Park, B.J.; Tyrväinen, L.; Kagawa, T.; Miyazaki, Y. Physiological and psychological effects of viewing urban forest landscapes assessed by multiple measurements. Landsc. Urban Plan. 2013, 113, 90-93. [CrossRef]

27. Lee, J.; Tsunetsugu, Y.; Takayama, N.; Park, B.J.; Li, Q.; Song, C.; Komatsu, M.; Ikei, H.; Tyrväinen, L.; Kagawa, T.; et al. Influence of forest therapy on cardiovascular relaxation in young adults. Evid. Based Complement. Altern. Med. 2014, 2014, 1-7. [CrossRef]

28. Park, B.J.; Kasetani, T.; Morikawa, T.; Tsunetsugu, Y.; Kagawa, T.; Miyazaki, Y. Physiological effects of forest recreation in a young conifer forest in Hinokage Town, Japan. Silva Fenn. 2009, 43, 291-301. [CrossRef]

29. Tsunetsugu, Y.; Park, B.J.; Ishii, H.; Hirano, H.; Kagawa, T.; Miyazaki, Y. Physiological effects of "Shinrin-yoku" (taking in the atmosphere of the forest) in an old-growth broadleaf forest in Yamagata prefecture, Japan. J. Physiol. Anthropol. 2007, 26, 135-142. [CrossRef]

30. Park, B.; Tsunetsugu, Y.; Ishii, H.; Furuhashi, S.; Hirano, H.; Kagawa, T.; Miyazaki, Y. Physiological effects of Shinrin-Yoku (taking in the atmosphere of the forest) in a mixed forest in shinano town, Japan. Scand. J. For. Res. 2008, 23, 278-283. [CrossRef]

31. Lee, J.; Park, B.J.; Tsunetsugu, Y.; Kagawa, T.; Miyazaki, Y. Restorative effects of viewing real forest landscapes, based on a comparison with urban landscapes. Scand. J. For. Res. 2009, 24, 227-234. [CrossRef]

32. Li, Q.; Morimoto, K.; Nakadai, A.; Inagaki, H.; Katsumata, M.; Shimizu, T.; Hirata, Y.; Hirata, K.; Suzuki, H.; Miyazaki, Y.; et al. Forest bathing enhances human natural killer activity and expression of anti-cancer proteins. Int. J. Immunopathol. Pharmacol. 2007, 20, 3-8. [CrossRef] 
33. Li, Q.; Morimoto, K.; Kobayashi, M.; Inagaki, H.; Katsumata, M.; Hirata, Y.; Hirata, K.; Suzuki, H.; Li, Y.; Wakayama, Y.; et al. Visiting a forest, but not a city, increases human natural killer activity and expression of anti-cancer proteins. Int. J. Immunopathol. Pharmacol. 2008, 21, 117-127. [CrossRef]

34. Li, Q.; Morimoto, K.; Kobayashi, M.; Inagaki, H.; Katsumata, M.; Hirata, Y.; Hirata, K.; Shimizu, T.; Li, Y.J.; Wakayama, Y.; et al. A forest bathing trip increases human natural killer activity and expression of anti-cancer proteins in female subjects. J. Biol. Regul. Homeost. Agents 2008, 22, 45-55.

35. Park, B. Effect of the forest environment on physiological relaxation-the results of field tests at 35 sites throughout Japan. For. Med. Nova Biomed. 2011, 66, 651-656.

36. Song, C.; Ikei, H.; Park, B.; Lee, J.; Kagawa, T.; Miyazaki, Y. Psychological benefits of walking through forest areas. Int. J. Environ. Res. Public Health 2018, 15, 2804. [CrossRef]

37. Woo, J.; Lee, Y.; Kim, D.; Cho, Y. Influence of Walking in the Forest Image on Aggression and Self-Esteem of Female Reformatory Facility Students. J. Korean Soc. People Plant. Environ. 2015, 18, 105-110. [CrossRef]

38. Jang, C.; Koo, C. Effects of after-school forest healing program activities on infant's pro-social behavior and self-efficacy. Korean J. Environ. Ecol. 2017, 31, 595-605. [CrossRef]

39. Sung, J.; Woo, J.M.; Kim, W.; Lim, S.K.; Chung, E.J. The Effect of Cognitive Behavior Therapy-Based "Forest Therapy" Program on Blood Pressure, Salivary Cortisol Level, and Quality of Life in Elderly Hypertensive Patients. Clin. Exp. Hypertens. 2012, 34, 1-7. [CrossRef]

40. Yu, Y.; Lee, Y.J.; Kim, J.Y.; Yoon, S.B.; Shin, C.S. Effects of forest therapy camp on quality of life and stress in postmenopausal women. For. Sci. Technol. 2016, 12, 125-129. [CrossRef]

41. Cho, Y.; Kim, D.; Yeoun, P.; Kwon, H.; Cho, H.; Lee, J. The influence of a seasonal forest education program on psychological wellbeing and stress of adolescents. J. Korean Inst. For. Recreat. 2014, 18, 59-69.

42. Park, S.; Yeoun, P.; Hong, C.; Yeo, E.H.; Han, S.M.; Lee, H.Y.; Lee, H.J.; Kang, J.W.; Cho, H.S.; Kim, Y.H. A study on the effect of the forest healing programs on teachers' stress and PANAS. Korean J. Environ. Ecol. 2017, 31, 606-614. [CrossRef]

43. Shin, W.; Yeoun, P.; Lee, J.; Kim, S.; Joo, J. The relationships among forest experience, anxiety and depression. J. Korean Inst. For. Recreat. 2007, 11, 27-32.

44. Lim, Y.; Kim, D.; Yeoun, P. Changes in depression degree and self-esteem of senior citizens in a nursing home according to forest therapy program. J. KIFR 2014, 18, 1-11.

45. Lee, I.; Choi, H.; Bang, K.S.; Kim, S.; Song, M.; Lee, B. Effects of Forest Therapy on Depressive Symptoms among Adults: A Systematic Review. Int. J. Environ. Res. Public Health 2017, 14, 321. [CrossRef]

46. Kaplan, R.; Kaplan, S. The Experience of Nature: A Psychological Perspective; Cambridge University Press: New York, NY, USA, 1989.

47. Ulrich, R.S.; Simons, R.F.; Losito, B.D.; Fiorito, E.; Miles, M.A.; Zelson, M. Stress recovery during exposure to natural and urban environments. J. Environ. Psychol. 1991, 11, 201-230. [CrossRef]

48. Shin, W.S.; Yeoun, P.S.; Yoo, R.W.; Shin, C.S. Forest experience and psychological health benefits: The state of the art and future prospect in Korea. Environ. Health Prev. Med. 2010, 15, 38-47. [CrossRef] [PubMed]

49. Pretty, J.; Peacock, J.; Hine, R.; Sellens, M.; South, N.; Griffin, M. Green exercise in the UK countryside: Effects on health and psychological well-being, and implications for policy and planning. J. Environ. Plan. Manag. 2007, 50, 211-231. [CrossRef]

50. Park, B.J.; Furuya, K.; Kasetani, T.; Takayama, N.; Kagawa, T.; Miyazaki, Y. Relationship between psychological responses and physical environments in forest settings. Landsc. Urban Plan. 2011, 102, 24-32. [CrossRef]

51. Morita, E.; Fukuda, S.; Nagano, J.; Hamajima, N.; Yamamoto, H.; Iwai, Y.; Nakashima, T.; Ohira, H.; Shirakawa, T. Psychological effects of forest environments on healthy adults: Shinrin-yoku (forest-air bathing, walking) as a possible method of stress reduction. Public Health 2007, 121, 54-63. [CrossRef]

52. Morita, E.; Imai, M.; Okawa, M.; Miyaura, T.; Miyazaki, S. A before and after comparison of the effects of forest walking on the sleep of a community-based sample of people with sleep complaints. BioPsychoSoc. Med. 2011, 5, 1-7. [CrossRef]

53. Tennessen, C.M.; Cimprich, B. Views to nature: Effects on attention. J. Environ. Psychol. 1995, 15, 77-85. [CrossRef]

54. Taylor, A.; Kuo, F.E.; Sullivan, W.C. Views of nature and self-discipline: Evidence from inner city children. J. Environ. Psychol. 2002, 22, 49-63. [CrossRef]

55. Hartig, T.; Evans, G.; Jamner, L.; Davis, D.; Garling, T. Tracking restoration in natural and urban field settings. J. Environ. Psychol. 2003, 23, 109-123. [CrossRef]

56. Berman, M.G.; Jonides, J.; Kaplan, S. The cognitive benefits of interacting with nature. Psychol. Sci. 2008, 19, 1207-1212. [CrossRef]

57. Berman, M.G.; Kross, E.; Krpan, K.M.; Askren, M.K.; Burson, A.; Deldin, P.J.; Kaplan, S.; Sherdell, L.; Gotlib, I.H.; Jonides, J. Interacting with nature improves cognition and affect for individuals with depression. J. Affect. Disord. 2012, 140, $300-305$. [CrossRef]

58. Speake, J.; Edmondson, S.; Nawaz, H. Everyday encounters with nature: Students' perceptions and use of university campus green spaces. Hum. Geogr. J. Stud. Res. Hum. Geogr. 2013, 7, 21-31. [CrossRef]

59. Föllmer, J.; Kistemann, T.; Anthonj, C. Academic Greenspace and Well-Being-Can Campus Landscape be Therapeutic? Evidence from a German University. Wellbeing Space Soc. 2020, 100003. [CrossRef]

60. Ibes, D.; Hirama, I.; Schuyler, C. Greenspace ecotherapy interventions: The stress-reduction potential of green micro-breaks integrating nature connection and mind-body skills. Ecopsychology 2018, 10, 137-150. [CrossRef] 
61. Green Flag Award. Raising the Standard. The Green Flag Award Guidance Manual. 2016. Available online: http://www. greenflagaward.org/ (accessed on 16 September 2019).

62. Universidad de Navarra. Available online: https://www.unav.edu/web/horizonte-2020/green-campus (accessed on 16 September 2019).

63. Gumprecht, B. The campus as a public space in the American college town. J. Hist. Geogr. 2007, 33, 72-103. [CrossRef]

64. Tudorie, C.; Vallés-Planells, M.; Gielen, E.; Arroyo, R.; Galiana, F. Towards a Greener University: Perceptions of Landscape Services in Campus Open Space. Sustainability 2020, 12, 6047. [CrossRef]

65. Felsten, G. Where to take a study break on the college campus: An attention restoration theory perspective. J. Environ. Psychol. 2009, 29, 160-167. [CrossRef]

66. McFarland, A.L.; Waliczek, T.M.; Zajicek, J.M. The relationship between student use of campus green spaces and perceptions of quality of life. HortTechnology 2008, 18, 232-238. [CrossRef]

67. Hipp, J.A.; Gulwadi, G.B.; Alves, S.; Sequeira, S. The relationship between perceived greenness and perceived restorativeness of university campuses and student-reported quality of life. Environ. Behav. 2016, 48, 1292-1308. [CrossRef]

68. Bang, K.; Lee, I.; Kim, S.; Lim, C.; Joh, H.; Park, B.; Song, M. The effects of a campus forest-walking program on undergraduate and graduate students' physical and psychological health. Int. J. Environ. Res. Public Health 2017, 14, 728. [CrossRef]

69. Zientek, L.; Nimon, K.; Hammack-Brown, B. Analyzing data from a pretest-posttest control group design: The importance of statistical assumptions. Eur. J. Train. Dev. 2016, 40, 8-9. [CrossRef]

70. McNair, D.; Lorr, M. An analysis of mood in neurotics. J Abnorm. Psychol. 1964, 69, 620-627. [CrossRef] [PubMed]

71. McNair, D.; Lorr, M.; Droppleman, L. Manual for the Profile of Mood States; Educational and Industrial Testing Service: San Diego, CA, USA, 1992.

72. Kim, E.; Lee, S.; Jeong, D.; Shin, M.; Yoon, I. Standardization and Reliability and Validity of the Korean Edition of Profile of Mood States (K-POMS). Sleep Med. Psychophysiol. 2003, 10, 39-51.

73. Shin, C.; Yeon, P.; Jo, M.; Kim, J. Effects of forest healing activity on women's menopausal symptoms and mental health recovery. J. People Plants Environ. 2015, 18, 319-325. [CrossRef]

74. Park, C.; Kim, D.; Park, K.; Shin, C.; Kim, Y. Effects of yoga and meditation-focused forest healing programs on profile of mood states (POMS) and stress response of adults. Korean J. Environ. Ecol. 2018, 32, 658-666. [CrossRef]

75. Yeun, E.J.; Shin-Park, K.K. Verification of the profile of mood states-brief: Cross-cultural analysis. J. Clin. Psychol. 2006, 62, 1173-1180. [CrossRef] [PubMed]

76. Koh, K.; Park, J.; Kim, C. Development of the Stress Response Inventory. J. Korean Neuropsychiatr. Assoc. $2000,39,707-719$.

77. Choi, S.; Kang, T.; Woo, J. Development and Validation of a Modified form of the Stress Response Inventory for Workers. J. Korean Neuropsychiatr. Assoc. 2006, 45, 541-553.

78. Im, S.; Choi, H.; Jeon, Y.; Song, M.; Kim, W.; Woo, J. Comparison of Effect of Two-Hour Exposure to Forest and Urban Environments on Cytokine, Anti-Oxidant, and Stress Levels in Young Adults. Int. J. Environ. Res. Public Health 2016, 13, 625. [CrossRef] [PubMed]

79. Hong, J.; Park, S.; Lee, J. Changes in depression and stress of the middle-aged and elderly through participation in a forest therapy program for dementia prevention. J. People Plants Environ. 2019, 22, 699-709. [CrossRef]

80. Suh, E.; Koo, J. A concise measure of subjective well-being (COMOSWB): Scale development and validation. Korean J. Soc. Personality Psychol. 2011, 25, 95-113.

81. Park, C.E.; Kim, D.J.; Shin, C.S.; Kim, Y. Effects of forest healing programs on resilience and happiness of employees-for university employees. Korean J. Environ. Ecol. 2018, 32, 667-675. [CrossRef]

82. Ochiai, H.; Ikei, H.; Song, C.; Kobayashi, M.; Takamatsu, A.; Miura, T.; Kagawa, T.; Li, Q.; Kumeda, S.; Imai, M.; et al. Physiological and psychological effects of forest therapy on middle-aged males with high-normal blood pressure. Int. J. Environ. Res. Public Health 2015, 12, 2532-2542. [CrossRef] [PubMed]

83. Bielinis, E.; Bielinis, L.; Krupińska-Szeluga, S.; Łukowski, A.; Takayama, N. The effects of a short forest recreation program on physiological and psychological relaxation in young polish adults. Forests 2019, 10, 34. [CrossRef]

84. Song, C.; Joung, D.; Ikei, H.; Igarashi, M.; Aga, M.; Park, B.; Miwa, M.; Takagaki, M.; Miyazaki, Y. Physiological and psychological effects of walking on young males in urban parks in winter. J. Physiol. Anthropol. 2013, 32, 18. [CrossRef]

85. Song, C.; Ikei, H.; Igarashi, M.; Miwa, M.; Takagaki, M.; Miyazaki, Y. Physiological and psychological responses of young males during spring-time walks in urban parks. J. Physiol. Anthropol. 2014, 33, 8. [CrossRef]

86. Song, C.; Ikei, H.; Igarashi, M.; Takagaki, M.; Miyazaki, Y. Physiological and psychological effects of a walk in urban parks in fall. Int. J. Environ. Res. Public Health 2015, 12, 14216-14228. [CrossRef] [PubMed]

87. Li, Q.; Kobayashi, M.; Kumeda, S.; Ochiai, T.; Miura, T.; Kagawa, T.; Imai, M.; Wang, Z.; Otsuka, T.; Kawada, T. Effects of forest bathing on cardiovascular and metabolic parameters in middle-aged males. Evid. Based Complement. Altern. Med. 2016, 2016, 2567381. [CrossRef] [PubMed]

88. Song, C.; Ikei, H.; Kagawa, T.; Miyazaki, Y. Effects of walking in a forest on young women. Int. J. Environ. Res. Public Health 2019, 16, 229. [CrossRef]

89. Morita, E.; Nagano, J.; Fukuda, S.; Nakashima, T.; Iwai, Y.; Yamamoto, H.; Hamajima, N. Relationship between forest walking (shinrin-yoku) frequency and self-rated health status: Cross-sectional study of healthy japanese. Jpn. J. Biometeorol. 2009, $46,99-107$. 
90. Marselle, M.; Irvine, K.; Warber, S. Examining group walks in nature and multiple aspects of well-being: A large-scale study. Ecopsychology 2014, 6, 134-147.

91. Khianman, B.; Pattanittum, P.; Thinkhamrop, J.; Lumbiganon, P. Relaxation therapy for preventing and treating preterm labour. Cochrane Database Syst. Rev. 2012, 8, CD007426. [CrossRef]

92. Choi, S.; Seok, J.; Park, I. An effect of free choice activity in forest on children's social competence and happiness. J. Korea Open Assoc. Early Child. Educ. 2013, 18, 181-198.

93. Kim, K.; Kang, Y. The effects of cooperative play in forest on young children's social competence and happiness. J. Korea Open Assoc. Early Child. Educ. 2016, 21, 209-239. [CrossRef]

94. MacKerron, G.; Mourato, S. Happiness is greater in natural environments. Glob. Environ. Change 2013, 23, 992-1000. [CrossRef]

95. Luck, G.; Davidson, P.; Boxall, D.; Smallbone, L. Relations between Urban Bird and Plant Communities and Human Well-Being and Connection to Nature. Conserv. Biol. 2011, 25, 816-826. [CrossRef] [PubMed]

96. Lohr, V.I.; Pearson-Mims, C.H. Responses to scenes with spreading, rounded, and conical tree forms. Environ. Behav. 2006, 38, 667-688. [CrossRef]

97. Van Herzele, A.; De Vries, S. Linking green space to health: A comparative study of two urban neighbourhoods in Ghent, Belgium. Popul. Environ. 2012, 34, 171-193. [CrossRef]

98. Nisbet, E.K.; Zelenski, J.M.; Murphy, S.A. Happiness is in our nature: Exploring nature relatedness as a contributor to subjective well-being. J. Happiness Stud. 2011, 12, 303-322. [CrossRef]

99. Zelenski, J.M.; Nisbet, E. Happiness and feeling connected: The distinct role of nature relatedness. Environ. Behav. 2014, 46, 3-23. [CrossRef]

100. Mahakud, G.; Yadav, R. Effects of happiness on mental health. Int. J. Indian Psychol. 2015, 2, 106-114.

101. Davidson, K.; Mostofsky, E.; Whang, W. Don't worry, be happy: Positive affect and reduced 10-year incident coronary heart disease: The Canadian nova scotia health survey. Eur. Heart J. 2010, 31, 1065-1070. [CrossRef]

102. Boehm, J.; Peterson, C.; Kivimaki, M.; Kubzansky, L. A prospective study of positive psychological well-being and coronary heart disease. Health Psychol. 2011, 30, 259-267. [CrossRef] [PubMed]

103. Chida, Y.; Steptoe, A. Positive psychological well-being and mortality: A quantitative review of prospective observational studies. Psychosom. Med. 2008, 70, 741-756. [CrossRef]

104. Koopmans, T.; Geleijnse, J.; Zitman, F.; Giltay, E. Effects of happiness on all-cause mortality during 15 years of follow-up: The arnhem elderly study. J. Happiness Stud. 2010, 11, 113-124. [CrossRef]

105. Diener, E.; Chan, M. Happy people live longer: Subjective well-being contributes to health and longevity. Appl. Psychol. Health Well Being 2011, 3, 1-43. [CrossRef]

106. Gana, K.; Broc, G.; Saada, Y.; Amieva, H.; Quintard, B. Subjective wellbeing and longevity: Findings from a 22-year cohort study. J. Psychosom. Res. 2016, 85, 28-34. [CrossRef] [PubMed]

107. Ong, A.; Kim, S.; Young, S.; Steptoe, A. Positive affect and sleep: A systematic review. Sleep Med. Rev. 2017, 35, 21-32. [CrossRef] [PubMed]

108. Ji, G.; Kim, K.; Han, G.-S. Physiological and Psychological Effects of Viewing and Walking in Forest and Urban Area. J. Environ. Sci. Int. 2012, 21, 605-611. [CrossRef]

109. Hayama, Y.; Inoue, T. The effects of deep breathing on 'tension-anxiety' and fatigue in cancer patients undergoing adjuvant chemotherapy. Complement. Ther. Clin. Pract. 2012, 18, 94-98. [CrossRef] [PubMed]

110. Perciavalle, V.; Blandini, M.; Fecarotta, P.; Buscemi, A.; Di Corrado, D.; Bertolo, L.; Fichera, F.; Coco, M. The role of deep breathing on stress. Neurol. Sci. 2017, 38, 451-458. [CrossRef]

111. Speca, M.; Carlson, L.; Goodey, E.; Angen, M. A randomized, wait-list controlled clinical trial: The effect of a mindfulness meditation-based stress reduction program on mood and symptoms of stress in cancer outpatients. Psychosom. Med. 2000, 62, 613-622. [CrossRef] [PubMed]

112. Tang, Y.; Ma, Y.; Wang, J.; Fan, Y.; Feng, S.; Lu, Q.; Yu, Q.; Sui, D.; Rothbart, M.K.; Fan, M.; et al. Short-term meditation training improves attention and self-regulation. Proc. Natl. Acad. Sci. USA 2007, 104, 17152-17156. [CrossRef] [PubMed]

113. Nidich, S.; Rainforth, M.; Haaga, D.; Hagelin, J.; Salerno, J.W.; Travis, F.; Tanner, M.; Gaylord-King, C.; Grosswald, S.; Schneider, R. A randomized controlled trial on effects of the transcendental meditation program on blood pressure, psychological distress, and coping in young adults. Am. J. Hypertens. 2009, 22, 1326-1331. [CrossRef]

114. Unsworth, S.; Palicki, S.K.; Lustig, J. The impact of mindful meditation in nature on self-nature interconnectedness. Mindfulness 2016, 7, 1052-1060. [CrossRef]

115. Lücke, C.; Braumandl, S.; Becker, B.; Moeller, S.; Custal, C.; Philipsen, A.; Müller, H.H.O. Effects of nature-based mindfulness training on resilience/symptom load in professional with high work-related stress-levels: Findings from the WIN-Study. Ment. Illn. 2019, 11, 20-24. [CrossRef]

116. Marchand, W.R.; Klinger, W.; Block, K.; VerMerris, S.; Herrmann, T.S.; Johnson, C.; Paradiso, N.; Scott, M.; Yabko, B. Mindfulness training plus nature exposure for veterans with psychiatric and substance use disorders: A model intervention. Int. J. Environ. Res. Public Health 2019, 16, 4726. [CrossRef]

117. Holt, E.; Lombard, Q.; Best, N.; Smiley-Smith, S.; Quinn, J. Active and passive use of green space, health, and well-being amongst university students. Int. J. Environ. Res. Public Health 2019, 16, 424. [CrossRef] 
118. Nelson, M.C.; Story, M.; Larson, N.I.; Neumark-Sztainer, D.; Lytle, L.A. Emerging adulthood and college-aged youth: An overlooked age for weight-related behavior change. Obesity 2008, 16, 2205-2211. [CrossRef]

119. Reynolds, E.K.; Magidson, J.F.; Mayes, L.C.; Lejuez, C.W. Risk-Taking Behaviors Across the Transition from Adolescence to Young Adulthood. In Young Adult Mental Health; Grant, J.E., Potenza, M.N., Eds.; Oxford University Press: New York, NY, USA, 2010; pp. 40-63.

120. Auerbach, R.P.; Mortier, P.; Bruffaerts, R.; Alonso, J.; Benjet, C.; Cuijpers, P.; Demyttenaere, K.; Ebert, D.D.; Green, J.G.; Hasking, P.; et al. The WHO World Mental Health Surveys International College Student Project: Prevalence and predictors of mental disorders. J. Abnorm. Psychol. 2018, 127, 623-638. [CrossRef]

121. Bamber, M.; Kraenzle Schneider, J. Mindfulness-based meditation to decrease stress and anxiety in college students: A narrative synthesis of the research. Educ. Res. Rev. 2016, 18, 1-32. [CrossRef]

122. Regehr, C.; Glancy, D.; Pitts, A. Interventions to reduce stress in university students: A review andmeta-analysis. J. Affect. Disord. 2013, 148, 1-11. [CrossRef] [PubMed]

123. Fiocco, A.J.; Hunse, A.M. The buffer effect of therapy dog exposure on stress reactivity in undergraduate students. Int. J. Environ. Res. Public Health 2017, 14, 707. [CrossRef] [PubMed]

124. Yu, C.; Lin, C.; Tsai, M.; Tsai, Y.; Chen, C. Effects of short forest bathing program on autonomic nervous system activity and mood states in middle-aged and elderly individuals. Int. J. Environ. Res. Public Health 2017, 14, 897. [CrossRef] [PubMed] 